\title{
'Pieces of kit' are not enough: the role of infrastructure in community resilience
}

\author{
Paula Orr ${ }^{1 a}$, Clare Twigger-Ross ${ }^{1}$, Katya Brooks $^{1}$ and Rolands Sadauskis ${ }^{1}$ \\ ${ }^{1}$ Collingwood Environmental Planning, Unit 1E The Chandlery, London SE17QY, England
}

\begin{abstract}
Flood resilience is about the ability of people and places to cope with, recover from and adapt to flooding in ways that maintain quality of life and identities. In the past UK flood risk management prioritised engineering solutions to prevent flooding (barriers, walls, etc); today there is greater emphasis on resilience. Cutter et al (2010) developed a model that describes community resilience capacities/resources in terms of social, institutional, infrastructure and economic resilience along with community capital. This paper draws on the findings of an evaluation of thirteen flood resilience community 'pathfinder' projects run in England between 2013 - 2015, which aimed to enable and stimulate communities to develop innovative local solutions and improve resilience to flooding. Actions to improve flood infrastructure included installing property resilience measures or setting up community flood stores providing equipment to deal with emergencies. The paper explores the way that 'infrastructure resilience capacities' were developed and examines how physical infrastructure contributed to community flood resilience. It finds that the development of infrastructure resilience depends on strong relations between community members ('community capital') as well as relationships between community organisations and flood management institutions ('institutional resilience'). The conclusions discuss the implications for infrastructure schemes in other places.
\end{abstract}

\section{Introduction}

Many people, experts and members of the public alike, have long been of the opinion that more effective flood risk management means greater investment in structural flood risk management measures such as embankments in order to move water away from homes, workplaces and infrastructure. However, increasing pressure on public spending has created a new policy context in the UK, with a shift towards localism and an emphasis on communities taking ownership of flood risk. The UK Environment Agency's Long-term Investment Scenarios (2014) report [1] stated that it will never be cost-effective for Government investment to protect everyone from flooding.

Between April 2013 - March 2015 Defra (the UK Government's Department of Environment Food and Rural Affairs) provided funding to support innovative community flood resilience measures carried out by 13 local authorities across England.

The Flood Resilience Community Pathfinder scheme was intended to enable and stimulate communities at significant or greater risk of flooding to work with key partners to develop innovative local solutions that:

- Enhanced flood risk management and awareness in ways which quantifiably improved the community's overall resilience to flooding.

- Demonstrably improved the community's financial resilience in relation to flooding.

- Delivered sustained improvements which could be applied in other areas.

Each pathfinder developed its own work programme, made up of a number of work packages focused on different aspects of resilience, with the focus depending on the priorities of the lead pathfinder organisation or local residents, and on the availability of resources (land and buildings as well as funding). Infrastructure resilience was the focus for 30 work packages.

\footnotetext{
a Corresponding author: p.orr@cep.co.uk
}

The scheme was evaluated by Collingwood Environmental Planning (CEP) and a consortium of expert project partners. Evaluating policy interventions of this kind generates valuable information and helps understand which actions work and are effective.

\section{UK flood community resilience pathfinders}

The 13 pathfinders covered areas at risk of different types of flooding (surface water, fluvial, coastal and sewer). Some areas had recent experience of flooding (for example the four northern pathfinders: Blackburn with Darwen, Calderdale, Liverpool and Rochdale). Other areas had not been flooded in living memory and residents were sometimes surprised to learn that they were in an area at flood risk. Several of the pathfinders were hit by storms and heavy rainfall in the winter of 2013-14. In places like Cornwall and Devon, the storms reminded people of the importance of becoming resilient to flooding.

All pathfinders were led by Local Lead Flood Authorities (LLFAs) but ranged in size from a community made up of two streets with 39 homes at flood risk to five pathfinders that included communities from across their areas: in Cornwall the pathfinder included 8,000 homes at flood risk. Figure 1 shows the location of the pathfinders.

Pathfinders received help in-kind from a range of partners, such as the Environment Agency, County Resilience Groups, water companies, fire services and Council departments. Eight pathfinders contracted the National Flood Forum (NFF), a national charity dedicated 


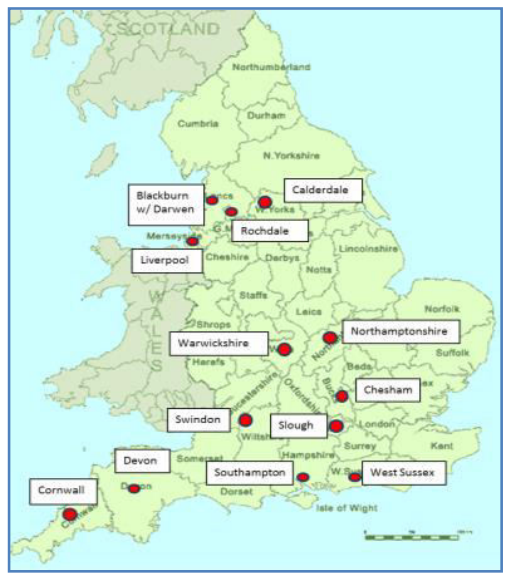

Figure 1. Location of the flood resilience pathfinders

to supporting and representing communities and individuals at risk of flooding) and had a member of NFF staff working in their Council offices on the community engagement aspects of the project. Working with communities to create awareness of flood risk and promote resilience measures was a central part of most of the pathfinders' work. Engagement methods included film festivals, community learning events, flood fairs and online information resources. All of the pathfinders also developed organisational mechanisms and structures specifically designed to deal with flood risk, such as flood action groups or flood wardens.

In the context of this scheme, infrastructure resilience refers to community and individual flood infrastructure. Individual infrastructure includes the type of housing and its inherent resilience (mobile homes and basement flats are known to be vulnerable to flooding), together with any measures people might have taken to increase their home's structural resilience to flooding ('property resilience measures'). Community flood infrastructure includes installations that increase overall resilience within an area. Some examples from the pathfinders were community flood stores providing access to basic equipment for use in flood events (such as high-visibility jackets and sandbags), rain gauges or measures to maintain and improve infrastructure such as drains.

\section{What is community resilience?}

The UK Department for International Development has a useful definition of disaster resilience as:

"...the ability of countries, communities and households to manage change, by maintaining or transforming living standards in the face of shocks or stresses - such as earthquakes, drought or violent conflict - without compromising their long-term prospects." [2]

This definition draws out the multi-dimensional nature of resilience and highlights the possibility of transformation of communities so that risks can be better managed or lived with.

Refining the definition further and thinking more about community resilience in the context of emergencies within the UK in particular, the following definition of community resilience provides a useful articulation of what the pathfinders were aiming for within their projects:

"Communities working with local resources (information, social capital, economic development, and community competence) alongside local expertise (e.g. local emergency planners, voluntary sector, local responders) to help themselves and others to prepare and respond to, and to recover from emergencies, in ways that sustain an acceptable level of community functioning " [3]

The focus on community goes beyond individual behaviour change to include the resilience of social networks and institutions relating to flood risk management.

An important aspect to note is that resilience can be of different types. Some types of resilience can be considered 'reactive', for example where resilience is seen as resistance, 'holding the line', being able to 'get back to normal' or 'bouncing back'. Other types of resilience are 'proactive', focusing on the ability to adapt to new conditions, recognition and ownership of the need to change or even transformation.

Understanding that there are different approaches to resilience helps to distinguish different strategies and to ask questions about the kind of resilience they promote.

This definition also draws attention to the issue of capacities that exist within communities which provide the foundation for resilience within the disaster/emergency situation. A number of authors [4 -7] suggest that communities need a certain set of capacities or resources or assets that can be drawn upon to address shocks and stresses.

Five categories of community resilience are provided within the Cutter et al (2010) paper: social, economic, institutional and infrastructure resilience, community capital, as shown in Figure 2. These categories relate to how communities 'engage' with (i.e. prepare for, withstand, respond to, and recover from) disasters taking the view that:

"Here resilience is [seen] as a set of capacities that can be fostered through interventions and policies, which in turn help build and enhance a community's ability to respond and recover from disasters". [8] 


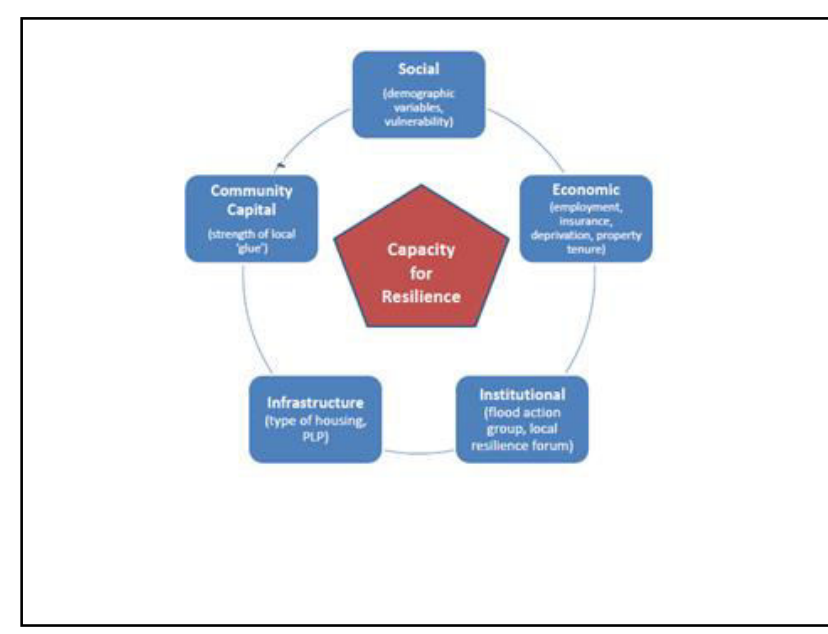

Figure 2 Characteristics of resilient communities

Infrastructure resilience is one of the sub-categories. For Cutter et al, [9], this is described in three ways: in relation to the amount of private property that may be particularly vulnerable to sustaining damage and economic loss (including mobile homes and basement properties); in terms of community response and recovery capacity (e.g. sheltering, vacant rental housing units, and healthcare facilities); and the existence of critical infrastructure such as road networks which allow for evacuation before an event as well as access for supplies and assistance for recovery.

These aspects of infrastructure resilience are generic to disasters and emergencies of all kinds. The pathfinder infrastructure measures tended to focus on increasing resilience to specific flood risks and impacts,

\section{Evaluation focus and indicators}

The pathfinder evaluation looked both at the impact of the scheme (what changed as a result of it, in terms of overall flood risk and in people's way of managing the risk) and the process itself (what aspects of the pathfinders worked well or less well and why).

In order to assess the change that occurred over the pathfinder period, the evaluation used indicators of resilience at community and household levels. In the case of the community-level indicators, these were based on the variables for each of the subcomponents of resilience used by Cutter et al [10] to construct their disaster resilience index and adapted to make them relevant to the UK and to the specific context of flooding. Table 1 shows the three community-level infrastructure resilience indicators.

\begin{tabular}{|l|l|l|}
\hline $\begin{array}{l}\text { Community } \\
\text { resilience } \\
\text { category }\end{array}$ & $\begin{array}{l}\text { Reason for } \\
\text { using indicator }\end{array}$ & Indicator \\
\hline $\begin{array}{l}\text { IN1: } \\
\text { Housing } \\
\text { style }\end{array}$ & $\begin{array}{l}\text { Temporary and } \\
\text { mobile homes } \\
\text { are less } \\
\text { resilient. }\end{array}$ & $\begin{array}{l}\text { \% housing units that are } \\
\text { not bungalows or mobile } \\
\text { homes } \\
\text { (Source: 2010 Census) }\end{array}$ \\
\hline $\begin{array}{l}\text { IN2: } \\
\text { Shelter } \\
\text { capacity }\end{array}$ & $\begin{array}{l}\text { The availability } \\
\text { of temporary } \\
\text { accommodation } \\
\text { makes it easier } \\
\text { to re-house } \\
\text { flooded people }\end{array}$ & $\begin{array}{l}\text { Units of accommodation } \\
\text { available for displaced } \\
\text { people } \\
\text { (Source: pathfinders) }\end{array}$ \\
\hline $\begin{array}{l}\text { IN3: } \\
\text { Recovery }\end{array}$ & $\begin{array}{l}\text { Evacuation } \\
\text { centres provide } \\
\text { a safe place for } \\
\text { people to go }\end{array}$ & $\begin{array}{l}\text { Number of schools/halls } \\
\text { as designated evacuation } \\
\text { centres within the area of } \\
\text { influence } \\
\text { (Source: pathfinders) }\end{array}$ \\
\hline
\end{tabular}

Table 1: Indicators of infrastructure resilience at community level

However, when it came to gathering baseline data for the community-level indicators, it was found that there were significant gaps on key aspects related to flooding. For example, in the case of infrastructure resilience, there are no national datasets for IN2 Shelter capacity and IN3 recovery. A request for data on these (and other) missing community-level indicators was made to Pathfinder project managers. Only two of the pathfinders (Chesham and Cornwall) provided data on IN2 for the Baseline Report, a further three provided data at the end of the project (Liverpool, Northamptonshire and Slough). The data obtained confirmed that local authorities generally do not keep properties specifically for emergency accommodation but tend to use the bed and breakfast providers that work with Social Services.

In relation to evacuation centres (IN3), seven pathfinders provided information about buildings (e.g. schools, leisure centres and community centres) that had been identified as evacuation centres within the areas. As a result of the Liverpool pathfinder, the community centre in the estate where the pathfinder was based agreed to be the rest centre for the local community and this is now included in the community plan. This represents a significant improvement in provision: previously evacuees would be taken by bus to a sports centre approximately three miles from the estate.

The evaluation also aimed to measure changes in the attitudes, knowledge and behaviour of individual participants in relation to the five resilience capacities. In order to assess how far the pathfinders brought about changes in individual attitudes, flood awareness and preparedness practices of participants, the evaluation team designed a household survey, which was applied locally by the pathfinders. Table 2 shows some of the household survey questions that are most relevant to infrastructure resilience. 


\begin{tabular}{|l|c|}
\hline \multicolumn{1}{|c|}{ Infrastructure Resilience } & $\begin{array}{l}\text { Number of } \\
\text { pathfinders } \\
\text { asking } \\
\text { question }\end{array}$ \\
\hline 1. Previously been flooded? & 10 \\
\hline $\begin{array}{l}\text { 2. Have you found out if your home is at } \\
\text { risk of flooding? }\end{array}$ & 7 \\
\hline $\begin{array}{l}\text { 3. "I believe the area in which I live is at } \\
\text { risk of flooding" }\end{array}$ & 5 \\
\hline $\begin{array}{l}\text { 4. "My own home is likely to be flooded } \\
\text { within the next 5 years" }\end{array}$ & 5 \\
\hline $\begin{array}{l}\text { 5. Do you believe your property is at risk } \\
\text { of flooding? }\end{array}$ & 9 \\
\hline $\begin{array}{l}\text { 6. "Preparing my home for future } \\
\text { flooding would be worthwhile" }\end{array}$ & 6 \\
\hline $\begin{array}{l}\text { 7. "There is little I can do to protect my } \\
\text { home from flooding" }\end{array}$ & 6 \\
\hline $\begin{array}{l}\text { 8. "I have a good understanding of how } \\
\text { to protect my home from flooding" }\end{array}$ & 6 \\
\hline $\begin{array}{l}\text { 9. "Have you thought through or prepared } \\
\text { a flood plan?" }\end{array}$ & 8 \\
\hline $\begin{array}{l}\text { 10. Have you undertaken any of the } \\
\text { following flood protection measures? } \\
\text { [followed by a list of property resilience } \\
\text { measures] }\end{array}$ & 5 \\
\hline
\end{tabular}

Table 2: Household survey: infrastructure resilience questions.

It was hoped that applying the survey at the start and end of the pathfinder process would give an idea of how much individuals' behaviours and attitudes had changed. However, in practice each pathfinder applied a different sub-set of questions and several applied the survey to different respondents at the start and end of the process, affecting the robustness of some of the data collected.

\section{Communities and infrastructure}

The discussion of the indicators used for measuring infrastructure resilience capacities highlights the difference between community infrastructure and conventional infrastructure which is managed by organisations and professionals outside the community. Infrastructure is very important for communities; one pathfinder project manager commented that while the local council felt that the main flood infrastructure was in place, the flood action group continued to make investment in drainage information and infrastructure their main priority. Infrastructure here is linked to information and capacities for the community to have a role in managing the risks.

The main community infrastructure interventions carried out as part of the pathfinders are described in the following sections.

\section{Pathfinder community infrastructure interventions}

\section{Property-level resilience}

Property-level resilience measures adapt individual properties to be less susceptible to flooding by preventing water getting in or reducing the damage caused by flood water (for example by moving electricity meters out of basements in Calderdale). These measures were included in nine of the pathfinder projects. Some measures can be described as 'fit and forget' (e.g. having mechanisms like permanent flood gates or non-return valves fitted), because they don't require the property owner to do anything differently. Other measures, like flood barriers, have to be put in place when there is a flood warning.

\section{Drainage}

Local communities are often very aware that blockages of river channels, drains and culverts can create a flood risk and this topic has been one of the main focuses when communities engage with risk management authorities. Several pathfinders took measures to promote collaboration between local residents or flood groups and the authorities in identifying actual or potential blockages:

- the Warwickshire pathfinder installed trash screens and CCTV cameras on rivers known to have problems of blockages;

- the Cornwall pathfinder set up a programme to train ex-offenders to clear leaf litter from drains and watercourses: as well as preventing blockages, this activity had positive social outcomes in terms of increasing participants' sense of being useful to their communities and gaining recognition from local people of the work they were doing;

- the Liverpool pathfinder brought representatives of local residents together with the authorities responsible for the local watercourses to discuss problems and improvements. Local people were already monitoring water levels in the brook flowing through their estate. Multi-agency meetings provided a forum in which local groups could raise issues about the management of rivers, culverts and drainage with the relevant authorities.

\section{Rain gauges}

Rain gauges were a popular infrastructure resilience measure in areas where there were no flood warnings (e.g. Cornwall, Devon) or where surface water rather than river flooding was the main risk (e.g. Northamptonshire, Warwickshire). The existence of simple, relatively cheap technologies for collecting rainwater and providing data to local people made this an attractive option for pathfinder action. For the rain gauges to provide an effective system of information and flood warning, they need to be maintained and there needs to be a system in place whereby the data generated is processed, the level of risk is assessed and where action is required, the information is passed on to residents and others who need it.

These requirements imply that rain gauges need to be part of a social infrastructure which connects the data produced with someone who has the capacity to translate it into meaningful and actionable information for local people. Subsequently, there needs to be a channel for the information to be taken to the people who need it, such as 
vulnerable people who need to contact families, carers or the authorities. Flood groups or flood wardens may often be the links between the information itself and the at risk community; mechanisms need to be in place to ensure this happens, particularly given that the time between receiving the warning and the onset of flooding may be extremely short.

\section{Flood stores}

Flood stores put equipment for managing a flood event within the community and the responsibility for distributing and using the equipment lies with the local group. This was particularly important in areas where there was a risk that the emergency services may not be able to arrive quickly (e.g. Liverpool and Northamptonshire) or where flooding was rapid (Calderdale and Devon).

\section{Flood defences}

The Southampton pathfinder installed temporary flood barriers which can be put in place to limit the possible flood flow routes to properties on one road that has flooded regularly in the past. This made it possible to reduce the risk of flooding to a number of properties which could not be covered by property-level resilience measures because of the lack of meaningful engagement with the residents. This highlights the need for community capital (networks and relations between members of the community) to support some types of community infrastructure.

\section{Promotion of catchment management and river stewardship}

The Calderdale and Rochdale pathfinders took measures to promote catchment management and river stewardship, through the involvement of schools and community volunteers in learning and action (Calderdale) or by incorporating stewardship activities into an existing growing project (Rochdale).

This kind of action was a positive way of increasing resilience rather than focusing on the resistance of built infrastructure. In both pathfinders the activities included a significant element of learning and capacity building. This means that future action can be more flexible and responsive to change; it also promotes adaptation to changing climate pressures.

\section{Implementing community infrastructure interventions}

Flood infrastructure has traditionally been an area of action for engineers and professionals, from which lay people were excluded. Many of the approaches to infrastructure resilience developed by the pathfinder challenged that distinction between expert and lay knowledge (and action), bringing the two perspectives together so that technical solutions could be informed by local knowledge with local people getting a better understanding of the level of protection offered by different measures.

Most of the pathfinders established or strengthened local flood groups. Where these groups were liaising regularly with the flood authorities (for example through multi-agency meetings), the management of local flood infrastructure was raised and discussed.

Most of the pathfinders have established or strengthened flood groups. Where these groups were liaising regularly with the flood authorities (for example through multi-agency meetings), the management of local flood infrastructure was raised and discussed.

The existence of flood groups or active local organisations was essential to this new approach to developing and strengthening individual and community flood infrastructure. Flood groups:

- Channelled lay knowledge to technical staff within local authorities, the Environment Agency, local water companies or private contracting companies, to inform the design or assessment of solutions;

Mobilised volunteers and resources in the community to implement some actions (e.g. catchment management or clearing ditches and culverts);

- Communicated with members of the community to explain actions and motivate participation, for example about community property level resilience programmes in Liverpool and Southampton.

Information about what infrastructure measures are more effective in reducing flood risk was often better received when it came from neighbours or community leaders rather than local authority staff or experts from outside the community. In Liverpool the tenants association offered to deliver letters from the council about the pathfinder by hand, so that they could talk to people individually and explain why the flood resilience work was important.

In some cases, flood resilience measures provided additional, non flood-related benefits to individuals or the community and these were an important 'selling point' and a factor in their uptake. Examples that were promoted locally were:

- The energy efficiency benefits of PLP measures. The Liverpool pathfinder emphasised the energy efficiency benefits of PLP and the associated reduction in energy bills as an argument to encourage take up. The Calderdale pathfinder was able to help a resident access funding for property-level resilience measures under an energy efficiency grant scheme. In future, Calderdale Council is intending to move responsibility for property level flood resilience to its building works department so that this kind of synergy can be maximised.

- The use in schools of the data produced by rain gauges for learning activities.

On the other hand, in places where flood groups were more recently formed and did not have the skills to act as intermediaries with members of the community, local authorities often struggled to communicate important aspects of the infrastructure resilience measures. For example, one project manager described difficulties in communicating the need for homeowners to take responsibility for the maintenance and care of property-level infrastructure: 
"Trying to convey to homeowners that they need to maintain the pumps and other PLP measures in order to keep resilient and safe, and to continue to keep aware of maintenance aspect, is a learning issue. "[11]

Another way in which the direct involvement of local groups in implementing infrastructure resilience measures improved the interventions was through the identification of simple solutions to meet local needs. One element of community infrastructure that was not included in any of the original pathfinder projects but was finally implemented by six pathfinders was the flood store. Flood stories provide essential equipment for local flood response and management, including sandbags and signage, which is vital in 'rapid response' catchments where flooding happens very suddenly and swiftly, or in communities less well served by the emergency services (a problem identified by residents of the Woodlands Estate in Liverpool. The Devon pathfinder noted that,

"Recent experience has shown that small deficiencies in a range of infrastructure can make a significant difference both to the risk of flooding itself but particularly the speed at which both individual householders and communities as a whole can respond. This is especially important in rapid response catchments. " [12]

With the flood stores, local people now have access to basic equipment like sandbags and signage.

\section{To what extent did the pathfinders succeed in building infrastructure resilience in their communities?}

Local groups became actively involved in drainage maintenance and were able to influence decision-making:

"Full survey done by flood group to plot all drains / culverts. [These are] Checked / cleared on a regular basis. One of our members has been on a course for this purpose. Through above work of flood group, parish council now able to work with Highways and South West Water on vital village drainage with more informed knowledge and experience." [13]

Across the pathfinders, the involvement of local groups led to numerous improvements being made:

"At a practical level, screens will be replaced. This is something the residents have wanted for a long-time but only the weight of the flood group gave them a voice that was heard by Thames Water." [14]

In terms of infrastructure for monitoring rainfall and flood water and providing warnings for local communities where this is not available from the national flood warning system, rain gauges were installed by four pathfinders (Cornwall, Devon, Northamptonshire and Warwickshire). In Devon readings from the stream level and rain gauges are fed into a system that provides emergency warning calls to coordinators and flood wardens.

The ownership of the rain gauges was usually been handed over to the local group or host institution (e.g. school). While it was acknowledged that this builds ownership, it was generally been a time-consuming process.

"As each location is dealt with individually, this engenders high level of ownership from the community in question, but it also takes time as separate meetings are needed to site and set up each gauge. Also land ownership permission is needed which can cause further delays. "[15]

In terms of the impact on flood risk, a stakeholder commented:

"The support of the projects on local community rainfall monitoring and telemetry systems, to provide triggers for community level response has also proved successful. The learning from this aspect of the project has been shared within our organisation, as it shows that communities often have a range of flood risks, from rivers to surface water, which they need to respond to and which may require different triggers. These triggers could be the Environment Agency Flood Warning Service but also may be supplemented by a locally managed trigger for surface water flooding from their rain gauge." [16]

In some cases, differences in perspective between community members or organisations and flood management authorities were a source of friction rather than innovation. In one pathfinder risk management authorities clashed with the flood action group over the siting of a flood store:

"It was unclear who had responsibility for the flood store so the placing of it was delayed. The community had taken account of the flood risk to the store through procedures while professionals wanted it out of the risk area. It almost resulted in the resignation of the whole group." [17]

Property-level infrastructure differs from the other types of infrastructure included in the pathfinders, in that measures generally involve individual properties and are the responsibility of the property owner. This was found to generate problems in some places, especially where there were high proportions of rented properties and low levels of community capital (see below). In Slough, a low income multicultural area, the pathfinder encountered found it hard to inspire interest in its offer of surveys and support for property-level resilience measures. The pathfinder documented the reasons given for people not wanting to be involved. These are shown in Table 3. 


\begin{tabular}{|c|c|}
\hline $\begin{array}{l}\text { General } \\
\text { issue }\end{array}$ & Challenge \\
\hline $\begin{array}{l}\text { Language } \\
\text { Barrier }\end{array}$ & $\begin{array}{l}\text { - Residents unable to read initial letters. } \\
\text { - Residents unable to communicate on } \\
\text { doorstep. }\end{array}$ \\
\hline $\begin{array}{l}\text { Cultural } \\
\text { Challenges }\end{array}$ & $\begin{array}{l}\text { - Challenge engaging with lone female } \\
\text { residents within some cultures. } \\
\text { - Female residents keen to have surveys } \\
\text { but not when husband not present. }\end{array}$ \\
\hline $\begin{array}{l}\text { Priorities } \\
\text { and Shift } \\
\text { Work }\end{array}$ & $\begin{array}{l}\text { - Residents reluctant to take time off } \\
\text { work for surveys. } \\
\text { - Residents do not know times they are } \\
\text { available in advance. } \\
\text { - Residents rarely available during } \\
\text { standard hours for engagement. }\end{array}$ \\
\hline $\begin{array}{l}\text { Property } \\
\text { Ownership }\end{array}$ & $\begin{array}{l}\text { - Residents did not feel responsible for } \\
\text { council or rental properties. }\end{array}$ \\
\hline $\begin{array}{l}\text { Financial } \\
\text { Implications }\end{array}$ & $\begin{array}{l}\text { Residents suspicious of our activity / } \\
\text { assume trying to sell products, } \\
\text { especially when they have not } \\
\text { experienced flooding first hand. }\end{array}$ \\
\hline $\begin{array}{l}\text { Other } \\
\text { Challenges }\end{array}$ & $\begin{array}{l}\text { Residents unwilling to work with } \\
\text { council directly for fear of } \\
\text { consequences e.g. reporting illegally } \\
\text { constructed buildings or multiple } \\
\text { occupancies. }\end{array}$ \\
\hline
\end{tabular}

Table 3. Challenges of arranging property level resilience measures identified by the Slough pathfinder

Some challenges, such as language barriers and cultural challenges could be overcome if there were an individual, group or organisation that had the trust of residents and was able to explain to residents the purpose of the measures. This was the approach used by the Liverpool pathfinder, which was also working in a lowincome neighbourhood, but one with strong community organisations and ties. The success of the programme of property-level resilience measures was attributed to engaging the community throughout the process and the involvement of a known respected neighbour who offered support on an ongoing basis and acted as a conduit between community members and contractors for installation scheduling. [18] In Southampton, the flood group came together around property-level resilience and procured the measures as a group with support from the local authority. The project manager for Southampton did not think the solution would have been as successful without the group.

\section{Challenges for building community-level infrastructure resilience}

Developing infrastructure for community resilience was generally more time-consuming than the pathfinders had expected. There were a number of reasons for this:

- Procurement - local authority processes aren't set up for procuring infrastructure / equipment to be managed outside the local authority:

- Responsibility for ongoing costs: there were problems in taking in actions where it was not clear who would be responsible for future maintenance costs. "...in addition to the initial capital cost, rain gauge equipment also incurs an annual subscription and maintenance cost which was seen as a potential burden to local communities. " [19]

- Ownership of locations where infrastructure is sited. When infrastructure was to be sited on private land, the pathfinders had to negotiate with private owners: in some cases, no agreement was reached and the works could not be carried out.

\section{Community capital and institutional resilience: key pieces in the resilience jigsaw}

\section{Community capital and infrastructure resilience}

Research suggests that community capital is a core capacity for building community resilience and that without it, related actions are not likely to succeed nor pathfinder objectives met [20-22]. Community capital is the 'glue' that keeps communities together and provides the foundations upon which community flood resilience can be built.

A key outcome of flood groups is the support they give in communities to people to improve flood resilience. Having a flood group helped in a number of pathfinders to support the uptake of property-level resilience measures. Where flood groups did not already exist, successful engagement was developed where time was taken to understand the needs of the community, although this may take considerable time and resources, especially in communities where existing capacities are weak.

Communities are better able to contribute to ensuring their own resilience if they are working with local authorities. Setting up flood groups and creating networks, for example through multi-agency meetings, has proved to be a very valuable way of linking members of the community with formal institutions and allowing a collaborative approach to infrastructure development and management. These structures are appreciated by community members and risk managers alike.

\section{Institutional and infrastructure resilience}

Institutional resilience focuses on the development of institutions, both formal and informal to support improved flood risk management. It includes both new institutions: e.g. flood groups and networks of groups, as well as activities that help to build resilience within and between existing institutions such as multi-agency meetings between local groups and flood risk management institutions. Broadly, it refers to the governance of flood risk management. The concept of governance considers the institutions, bodies or organisations involved in decision-making processes to consist of more than just 'government'. It may consist of a wider range of formal and informal bodies. 
The broader literature on governance, from the social sciences, recognises that initiative and decision making processes do not take place exclusively at the state level but within an increasingly pluralistic structure of agents at different spatial scales. The concept of multilevel governance suggests that governance takes place through processes and institutions operating at a variety of geographical scales including a range of actors with different levels of authority [23]. Actors are not just government bodies but may include private businesses, community organisations, voluntary sector bodies and other NGOs, as well as influential individuals.

Pathfinders focussed considerable effort to develop and enhance informal institutions and community voice in flood risk management as well as developing links between those informal institutions and formal institutions of government at the local level. In many cases, community infrastructure provided the focus for groups' efforts:

- In the Chesham pathfinder, the flood group changed the priorities from a focus on planning to a focus on infrastructure:

"The project had initially planned for CFLAG [Chesham Flood Action Group] to create an emergency flood plan and subsequently take part in a flood response training exercise. However, CFLAG felt they would rather concentrate on improving infrastructure and its flood resilience as a priority, and the group was supported further in achieving their own aims. " [24]

- In West Sussex, small grants provided by the local authority were used by many groups for infrastructure investments.

\section{Conclusions and transferability}

The experience of the flood pathfinder scheme in England indicates that "pieces of kit" such as propertylevel resilience measures, flood stores and local drainage systems do not on their own ensure flood resilience but that it is vital that they are part of a wider community resilience-building process that develops local relationships and capacities. These include strong links and networks between people within at risk communities, formal and informal relationships between community members and their organisations with the authorities responsible for managing flood risk and increased understanding of their own flood risk, how infrastructure and equipment can help to reduce it and how it should be effectively managed and maintained.

For the pathfinders, community involvement was central to the delivery of project interventions, including infrastructure measures. Examples of other recent research at the European level $[25,26]$ indicate that this is common across many countries. The implementation of the European Floods Directive [27] presents an opportunity to encourage greater involvement of at risk communities. One study indicates that there is considerable variety in the approaches being taken by authorities to the implementation of the Directive's provisions for public participation, "as well as a general trend to 'less' rather than 'more' participation as compared to the WFD [Water Framework Directive]" [28]. In this context, it seems important to provide examples of the benefits of engaging affected communities, in aspects such as improving the effectiveness of local infrastructure.

Infrastructure often provided a focus for local people to come together and for coordination between authorities, agencies and citizens. The pathfinder scheme provided valuable learning on the synergies between action to build relationships (both in terms of developing community capital at the local level and institutional resilience through the strengthening of relations between institutions and community organisations) and practical measures to install or improve community infrastructure. The following key learning points were identified:

- Infrastructure is an important part of community resilience: having the right infrastructure makes communities better able to manage and cope with flooding while at the same time the process of developing infrastructure is key to building community capacity for flood resilience.

- It is important to work out what is needed with all the local community, to ensure that any infrastructure can be managed by local people or groups and that support is provided where necessary to develop or create capacity to manage and maintain the 'kit'.

- Sufficient time needs to be allowed to work out how to procure community flood infrastructure, because local authority procurement rules are not usually geared to this kind of process.

- Much individual infrastructure, like property-level protection, works better as part of a community resilience process or package rather than in isolation.

\section{References}

1. Environment Agency. (2014) Flood and coastal erosion risk management: Long-Term Investment Scenarios.

2. DFID (2011) Defining Disaster Resilience: A DFID Approach Paper. London: Department for International Development. p6

3. Adapted from Twigger-Ross, C., Coates, T., Deeming, H., Orr, P., Ramsden, M. and Stafford, J. (2011) Community Resilience Research: Final Report on Theoretical research and analysis of Case Studies report to the Cabinet Office and Defence Science and Technology Laboratory. London: Collingwood Environmental Planning Ltd. p11.

4. Norris, F.H., Stevens, S.P., Pfefferbauam, B., Wyche, K.F. and Pfefferbaum, R.L. (2008) 'Community resilience as a metaphor, theory, set of capacities, and strategy for disaster readiness', American Journal of Community Psychology, 41(12):127-150.

5. Cutter, S.L., Burton, C.G. and Emrich, C.T. (2010) 'Disaster Resilience Indicators for Benchmarking Baseline Conditions', Journal of Homeland Security and Emergency Management, 7(1): 1-22. 
6. Middlemiss, L. and Parrish, B. (2010) 'Building capacity for low carbon-communities: the role of grassroots initiatives'. Energy Policy, 38(12): 7559-7566

7. Young Foundation (2012) Adapting to Change: The Role of Community Resilience. London: The Young Foundation

8. Cutter et al (2010). Op cit.

9. The Young Foundation (2012). Op cit.

10. Twigger-Ross, C., Orr, P., Brooks, K., Sadauskis, R., Deeming, H., Fielding, J., Harries, T., Johnston, R., Kashefi, E., McCarthy, S., Rees, Y. and Tapsell, S. (2015). Flood Resilience Community Pathfinder Evaluation. Final Report FD1664. Defra, 2015.

11. Op cit. p149.

12. Devon County Council (2015) Flood Resilience Community Pathfinder Project. Final Report April 2015. p16.

13. Twigger-Ross et al. (2015). Op cit, p153

14. Ibid

15. Ibid, $\mathrm{p} 154$

16. Ibid

17. Ibid

18. Ibid, $\mathrm{p} 155-56$

19. Ibid, p157

20. Cinderby, S., Haq, G., Cambridge, H. and Lock, K. (2014) Practical Action to Build Community Resilience: The Good Life Initiative in New Earswick. York: Joseph Rowntree Foundation

21. Twigger-Ross, C., Kashefi, E., Weldon, S., Brooks, K, Deeming, Hugh, Forrest, S., Fielding, J., Gomersall, A., Harries, T., McCarthy, S., Orr, P., Parker, D. and Tapsell, S. (2014) Flood Resilience Community Pathfinder Evaluation: Rapid Evidence Assessment. Project Report. London: Defra

22. The Young Foundation (2012). Op cit.

23. Hooghe, L. and Marks, G. (2003) 'Unravelling the central state, but how? Types of multi-level governance.' American Political Science Review, 97(2): 233-243

24. Twigger-Ross et al. (2015). Op cit, p131

25. Uyttendaele, G., van der Craats, I., Schelfaut, K., Krywkow, J. and Mysiak, J. (2011) FREEMANFlood Resilience Enhancement and Management: a pilot study in Flanders, Germany and Italy. CRUE Final Report.

26. Kuhlicke, C., Steinführer A., Begg, C. \& Luther, L. (2012): Toward More Resilient Societies in the Field of Natural Hazards: CapHaz-Net's Lessons Learnt. CapHaz-Net WP10 Final Report. Available at: www.caphaz-net.org

27. European Union (2007) Directive 2007/60/EC of 23 October 2007 on the assessment and management of flood risks. OJ 288/27

28. Newig, J., Challies, E., Jager, N and Kochskämper, E. (2014) What Role for Public Participation in Implementing the EU Floods Directive? A Comparison With the Water Framework Directive, Early Evidence from Germany and a Research Agenda. Environmental Policy and Governance.
Volume 24, Issue 4, pages 275-288, July/August 2014. 